\title{
En sovsekande $i$ forsvindingspunktet
}

\section{SØREN POLD}

\section{Sovsekanden}

Henrik Bjelkes „Time out" er en lille kompliceret novelle, hvor et jeg fortæller om sit ensomme ophold i et sommerhus. Han har imidlertid en række problemer med at fortælle; problemer som forstyrer hans fortælling indtil det punkt, hvor man kan diskutere, om der overhovedet er tale om en fortælling.

Allerede i novellens første linier står der en sovsekande i vejen. Oven i købet en mærkværdig sovsekande, som er svær at få til at materialiseres for sit indre blik, på trods af en udførlig beskrivelse med geometrisk nøjagtighed: „Det var en sovsekande med parallelle sider, så den lignede et rektangel, men den var buet $i$ enderne som en båd, en fladbundet båd med en cirkelrund forsænkning i midten."

Denne sovsekande står i sommerhusets køkken og oven i den står en flaske med en hvid prop, "som passede lige så fint ned i bunden af sovsekanden." Og sovsekanden eller rettere beskrivelsen af den, står i vejen; både for fortælleren og læseren. Hvad er meningen?

Imidlertid viser det sig lidt efter, at sovsekanden ikke eksisterer, men var en drøm. Fortæller-jeget fortæller, hvordan hans bevidsthed startede sin refleksion umiddelbart efter at have konstateret, at flasken i sovsekanden havde en hvid prop. Han undrede sig over, hvem der havde stillet denne ukendte genstand i hans køkken, mens han sov. Indtil han blev bevidst om, at han stadig sov, ikke var stået op, og altså ikke havde set den sovsekande, som var årsagen til hele refleksionsrækken. Han blev med andre ord bevidst om, at han ikke var ved bevidsthed. 
Novellens realitetsniveauer - drøm/virkelighed og bevidst/ubevidst - foldes allerede indledningsvis omkring noget så absurd som en ikke-eksisterende sovsekande af besynderlig udformning. Fortælleren forsøger selv $i$ en efterrationalisering at gøre rede for denne paradoksale tilstand af ubevidst bevidsthed eller bevidst ubevidsthed, som åbner novellen:

På denne måde blev forskellen mellem at ligge og sove og ikke ligge og sove men være stået op til dels udslettet. Ingen forskel mellem bevidst og ubevidst, og derfor findes ingen bevidsthed, eller også er man forsvindingspunktet i en eneste stor bevidsthed.

Men han snubler endnu engang over sovsekanden med flasken, må give op og starte sin fortælling forfra i et nyt forsøg. Det nye forsøg bærer dog stadig et spor af det gamle, mislykkede forsøg; nemlig den ikke-eksisterende sovsekande: „Jeg lå og sov og troede, at jeg var stået op, og da jeg opdagede, at jeg ikke var stået op, stod jeg op. Og der stod ikke nogen sovsekande med nogen flaske ude i køkkenet, der stod ikke nogen fremmede ting der." Den indledende, ikke-eksisterende genstand, som fortællingen snublede over, er dermed ryddet af vejen, og vi kan gå videre med den paradoksale fortælling om fortællerens ophold alene i et sommerhus. Et ophold hvor han gennem et intenst sprogligt arbejde (novellen) forsøger at undslippe civilisationens kategorier som for eksempel tid, rum, sprog og subjekt.

\section{Forskellen mellem dag og nat eller landet og byen}

En af retorikkens, og senere strukturalismens, centrale og mest stabile figurer er antitesen. Antitesen strukturerer vores sprog, som igen strukturerer vores virkelighedsopfattelse. Roland Barthes skriver for eksempel om "antitesens mur", som opretholder adskillelsen mellem antitesens to modpoler. Denne mur danner rygrad i sprogets system og holder betydningen på plads. ${ }^{1}$

„Time out" er i høj grad opbygget omkring antitetiske modsætninger og en undersøgelse af deres forhold til hinanden. 
Grundlæggende antitetiske strukturer som indenfor vs. udenfor, dag vs. nat og by vs. land og, som vi allerede har set, bevidst vs. ubevidst samt drøm vs. virkelighed bruges og undersøges af fortælleren i en grad, der med tydelighed demonstrerer, at der må være noget betydningsfuldt på færde her.

Umiddelbart efter sovsekandeepisoden kan fortælleren ikke bestemme sig for, om han vil sidde udenfor eller indenfor. Så han sidder henholdsvis indenfor og udenfor "uden at der egentlig er nogen særlig stor forskel..." Den eneste forskel er, at han trækker vejret bedre udenfor og får hovedpine indenfor. Men det skyldes måske de elektriske varmeapparater, som han slukker, og i stedet tænder han op i kaminen. Så i fortælleøjeblikket, markeret af et "Nu", kan fortæller-jeget ",sidde inde hele tiden - og have det, som om jeg sad udenfor."

Forskellen mellem de antitetiske modsætninger indenfor og udenfor udlignes uden den store dramatik. ${ }^{2}$ Og trods denne udligning er der stadig forskel, og fortælleren er ikke i tvivl og får ikke umiddelbart destrueret sit sprog. Men fortælleren har trods begrebernes og antitesens tilsyneladende stabilitet problemer med at indkredse, hvor det er, forskellen opstår; hvor antitesens mur, den grundlæggende forskel som stabiliserer betydningen og holder de antitetiske poler på plads, befinder sig. Fortælleren fortsætter med at spekulere over, hvor forskellene egentlig befinder sig i en sætning, hvor et ", dog" røber, at han trods alt er rystet: "Jeg mærkede dog en forskel mellem dag og nat, eller også var det en forskel mellem at være på landet og være i byen..." Måske er det hyldetræernes duft, duften af andre planter, græsset, træerne, der udgør forskellen på det, som fortælleren ikke er helt sikker på er dag og nat eller byen og landet. For om dagen lugter det slet ikke af noget, heller ikke af benzin fra byens trafik, og for at komplicere tingene yderligere er det hele tiden gråvejr, hvilket får fortælleren til at konkludere: „Der er noget af det man kalder nat, og noget andet man kalder dag. Men det er ikkestrengt nødvendigt for mig at opretholde denne sondring... " Fortælleren befinder sig i et uddifferentieret nu, hvor "den herskende situation er jævnt tåget, et jævnt gråligt billede, som står fuldstændig ubevægeligt dag og nat..." Selvom der ud fra de sproglige, begrebs- 
lige definitioner er absolut forskel, kan fortælleren ikke finde ud af, hvori forskellene præcist består. Så begreberne mister deres absolutte, enten-eller, betydning og bliver tiltagende diffuse og meningsløse for fortælleren.

\section{Virkelighedens tid}

I sin forgæves søgen efter de forskelle, der konstituerer det antitetiske, begrebslige sprog, bl.a. forskellen mellem nat og dag, er fortælleren allerede gledet videre til at opbryde en anden af de strukturer, som konstituerer og afgrænser vores sproglige virkelighedsopfattelse: tiden. Han læser lidt i (formodentlig Baudrillards) Amerika, hvor uendelighed bruges som et beskrivende træk på flere niveauer. Efter at have genkendt fornemmelsen af "disse evige motorveje", "de store tomme ørkener"., "de store vidder og de ensomme mennesker", "det endeløst vulgære" når han til Baudrillards bud på fremtiden og konkluderer med Baudrillard, at det er „som om fremtiden allerede er her." Men denne konstatering skyldes snarere, at fortælleren ikke har en klar opfattelse af nutiden, end den skyldes et klart, håndgribeligt fremtidssyn. Fortælleren har ingen meningsfuld struktur på sin nutid, hvilket også angives af følgende citats opremsende sideordninger og manglende underordning eller strukturering: „Der er nogle ting og nogle genstande og nogle træer og noget vand og nogle marker, men det er mere eller mindre tomt for betydning."

Opholdet i sommerhuset mangler den redundans og forudsigelighed, der danner afsæt for timernes kronologi. Fortælleren har ikke noget tv, og selvom der er en radio, mangler han et radioprogram, så radioen kan heller ikke „strukturere noget af det stykke tid", som opholdet varer. Den kronologiske tid mister sin mening over for fortællerens "ustrukturerede ophold", hans virkelighed: „Det er ikke noget billede på den virkelighed, jeg oplever, at jeg kalder det tyve timer. Jeg kalder det et stykke væren her mere eller mindre bevidst, mere eller mindre bevidstløs..."

Både urets og døgnets rigide kronologi, samt mere svævende tidsbegreber som fortid, fremtid og evighed, opløses i nuets eller 
øjeblikkets mere eller mindre ubevidste „stykke væren" i det tomme, med stor anstrengelse tømte landskab. Netop fordi øjeblikket er så tømt, rummer det et uendeligt potentiale; en form for (af fortælleren) begrænset evighed, som gemmer et urealiseret „kvantum muligheder for erindring“. Landskabet skal tømmes for præsens, fordi „det ikke skal farves ind af nogen tilstedeværelse, der vedrører lige nu, i dette år, i denne uge, på denne dag, i denne time“, for derefter at kunne åbne for „nogle dimensioner af en anden art". Men samtidig med præsens fjernes jeget fra tidens dimension i mødet med havet: "Så er jeg uden for tiden, eller også er jeg al den tid, jeg har haft, samlet i ét øjeblik af tid. Synet af havet fratager mig min alder."

Sprogets postulerede nærvær, herunder dets grammatiske hovedtid, præsens, viser sig på denne måde at være fremmed og fremmedgørende i forhold til oplevelsen af eller kontemplationen i landskabet. Og som om det ikke skulle være nok, slutter "Time out" med, at fortælleren i allersidste sætning fjerner det sidste fundament under sproget: brugen af perfektum-formen, som er forudsætningen for erfaring og benævnelse. Hvis intet nogensinde er perfektivt afsluttet, er al erfaring, benævnelse og dermed sprog fremmedgørende $i$ forhold til virkelighedens strømmende og aldrig afsluttede verden. Og hvis sproget, som antaget i moderne sprogvidenskab, er et arbitrært system af forskelle, så mister det den sidste rest af stringens, når selve begrebet og ideen om forskel drages så voldsomt i tvivl som i „Time out".

Novellen ind i landskabet den bukker og takker og går ud igen.

\section{Topografien og beskrivelsens sprængning}

Topografien "Time out"3 arbejder hårdt på at beskrive et forholdsvis ubetydeligt sted, uden at stedsbeskrivelsen får nogen selvstændig status eller autoritet over for stedet. Stedsbeskrivelsen prøver forgæves på at slå rod i stedet, men dens forskellige struktureringer viser sig hele tiden afmægtige over for stedets eneståenhed. Hvad enten stedsbeskrivelsen forsøger sig med tidsmæssige, retoriske eller geometriske strukturer, er ste- 
det nøgent efter, at beskrivelsen har rullet hen over det, og ingen af beskrivelsens strukturer har bidt sig fast og givet stedet betydning.

Der, hvor stedsbeskrivelsen kommer tættest på stedet, er i dens negativitet, dens (selv)destruktion og erkendelse af egen uformåen. Men ikke engang i beskrivelsens negative kategorier for det, den ikke magter (det uendelige, tomme, betydningsløse, diskrete, det Andet) stiller fortælleren sig tilfreds. Beskrivelsen er som en støbeform, der til sidst må slås i stykker for at efterlade stedet. Eller også er det snarere stedet, der gennem minutiøs iagttagelse udvider sig og sprænger beskrivelsen og bevidstheden. Som i episoden med det brændende stykke træ, der hopper ud af en lukket kamin, hvilket ikke så meget får fortælleren til at sætte spørgsmålstegn ved kaminens og træets beskaffenhed men snarere sin egen. Om han overhovedet er til stede i virkeligheden eller er noget, en anden har drømt. Om hans bevidsthed findes $i$ virkeligheden eller kun er „forsvindingspunktet i en eneste stor bevidsthed."

\section{Havet, landskabet og menneskene}

Det flydende, uendelige, ikke substantielle, farveløse, uforanderlige; "dette endeløst ligeglade"; havet bliver ironisk nok udnævnt til det eneste, som giver fortælleren en „følelse af konstans i tilværelsen". Havet ophæver sammen med det grå, unuancerede "anakronistiske landskab" tiden og overskrider samtlige klassifikationer. Havet reducerer al betydning til krusninger på overfladen. Det tomme landskab ophæver enhver skelnen og forskel og gør intet lig med alt.

Men til fortællerens store irritation kommer der af og til tilfældigt mennesker og biler forbi. Eller måske er det ikke spor tilfældigt men skyldes en "mærkelig form for idiotisk magnetisme“, at folk altid kommer forbi lige netop, når fortælleren selv vil ud i landskabet, ned til havet. Landskabet er selvfølgelig endeløst ligeglad i sin uendelige tolerance, men fortællerens tolerancetærskel er lav. Ellers ville han jo heller ikke være i stand til at registrere forskelle og blive irriteret over, at han ikke kan finde deres 
substans. Fortællerens kontemplation, hans ureflekterede væren et stykke tid i landskabet, bliver spoleret af mødet med andre reflekterende væsner. Han registrerer, at han bliver registreret, og hans registrerende, forskelssøgende bevidsthed vågner dermed af sin dvale. Landskabet, og specielt jegets kontemplation i det, bliver med andre ord ødelagt af (andres) bevidsthed.

Paradoksalt nok er timing det eneste, der kan forhindre fortælleren i at vågne fra sin time out. Han må planlægge ikke at møde disse tilfældigt forbipasserende. Men i og med planlægningen er den bevidstløse tilstand allerede ødelagt: „[Men] hvordan skulle jeg bære mig ad med at undgå møder, når jeg blot ønsker at følge mine impulser ureflekterende, u-existerende, præcis som landskabet selv, som jeg føler mig ud i et med, lige så gråt, tåget og udflydende det er?"

Ved at møde andre reflekterende, registrerende, forskelssøgende, sproglige mennesker bliver jeget konfronteret med den smertelige erkendelse, at han er ligesom dem og dermed ikke en del af det ureflekterende landskab. Den klassiske natur/kultur-dichotomi træder i kraft, og jeget sparkes tilbage i sprogets og refleksionernes spændetrøje. Den tredje position, hvorfra antiteserne kan ophæves, utopien eller atopien hinsides de sproglige paradokser, viser sig at være en yderst sproglig illusion, der altid allerede er umuliggjort; selvom det så blot er tilfældigheder, der ødelægger den. Mennesket er et betydningsskabende dyr.

\section{Forsvindingspunktet}

Fortælleren ønsker at være til stede i landskabets forsvindingspunkt, hvor synet af havet, landskabet og det uendelige reducerer ham til ubetydelighed. Men ligesom den yderst sproglige utopi om at befinde sig hinsides sproget og refleksionerne er forsvindingspunktet en illusion, der bruges til at illustrere uendeligheden inden for perspektiv; forsvindingspunktet er det punkt i billedets horisont, hvor de indadførende linier mødes. 4 Forsvindingspunktet findes ligesom horisonten ikke i virkeligheden men er blot perspektivets måde at afbilde sin egen 
begrænsning over for virkelighedens ubegrænsede uendelighed. Forsvindingspunktet, bevidstheden, subjektets begrænsning over for objekterne i virkeligheden samt sprogets stedsbeskrivelse er i „Time out" ligedannede og parallelle størrelser. Novellen færdes aldeles uhysterisk i en række paradokser, der ophæver og reducerer gængse klassifikationer til absurditeter, herunder tid, retorik, sprog, rum, geometri, subjekt/objekt. Hvorefter den til sidst trækker sig selv tilbage ligesom sovsekanden i novellens begyndelse. Men ligesom sovsekanden har den efterladt et spor eller afsat et forsvindingspunkt $i$ virkeligheden. Novellen bider sig selv i halen i sin uendelige selvrefleksion, opløser sig selv men efterlader en fornemmelse af stedet i dets strukturløse, forskelsløse væren her et stykke tid. Det sted som måske paradoksalt nok er sprogets eneste stabile referencepunkt, selvom det kun kan beskrive det indirekte, ligesom havet er fortællerens eneste konstans.

Sådan placerer Henrik Bjelkes geniale topografi sig i forhold til dens topos, som den efterlader næsten uberørt og uspoleret; kun med et forsvindingspunkt, eller måske er det en sovsekande, knap synlig i horisonten.

Og tekstanalysen? Hvor befinder den sig i forhold til teksten? I sovsekanden selvfølgelig, måske endda gemt i flasken som en skjult besked, der må foldes ud. Tekstanalysen er som sovsekanden skabt i geometrisk regelmæssighed, og samtidig er den bådlignende. Det kan være svært at forestille sig, hvordan tekstanalysen ser ud i virkeligheden. I forhold til teksten er den ikkeeksisterende men måske netop synlig i tekstens forsvindingspunkt i horisonten, på havet. Hvorfra den iagttager, hvordan teksten snubler og folder sig omkring sin virkelighed. 


\section{Noter:}

1. Roland Barthes: $S / Z$, Éditions du Seuil, 1970, p. 221

2. Specielt hvis man sammenligner med Roland Barthes' $S / Z$ og den novelle, han analyserer i $S / Z$; "Sarrasine" af Honoré de Balzac. I "Sarrasine." er en lang række økonomier forbundne og sammenvævede; bl.a. sprogets, kroppens, kønnenes, guldets og fortællingens. Alle disse økonomier kollapser i, hvad der både hos Balzac og Barthes er dramatiske, paroksystiske højdepunkter. Sammenlignet med dette er "Time out" yderst afdæmpet.

3. Henrik Bjelke kalder meget præcist novellerne i samlingen Nattens Budapest for topografier. Topografi bliver på omslagets bagside defineret via (noget der i hvert fald ligner) et ordbogsopslag: "Topografi: gr. (topos, Sted; grafein, skrive), Stedskildring, Beskrivelse i det enkelte over Steder el. Egne, ogs. over et Distrikt el. helt Land." -Topografien som form bliver i øvrigt udførligt behandlet andetsteds i dette nummer af Passage af Marianne Ping Huang.

4. Lise Gottfredsen forklarer det f.eks. således i sin lærebog Billedets formsprog (Viborg 1993): „Linearperspektivet består egentlig i, at man forbinder størrelsesgradienterne med hinanden ved hjælp af virkelige eller tænkte linjer. Disse indadførende linjer kaldes orthogonaler. Det punkt, hvori de mødes, er forsvindingspunktet." (p. 73) 
